\title{
KEPUTUSAN INVESTASI DAN PENDANAAN TERHADAP NILAI PERUSAHAAN SUB SEKTOR PERKEBUNAN
}

\author{
Emi Ernawati \\ emiernawati5@gmail.com \\ Ellen Rusliati \\ Universitas Pasundan
}

diterima: 13/5/2019; direvisi: 27/5/2019; diterbitkan: 31/8/2019

\begin{abstract}
This study aims to determine the influence of investment decisions and funding decisions on the value of the company in the agricultural sector companies in the plantation sub-sector listed on the Indonesia Stock Exchange for the period 2008-2017. The method used in this research is descriptive and verificative. The samples are 6 companies. Sampling is done by purposive sampling. Data analysis method used are panel data regression analysis and determination coefficient. Statistical analysis process uses Eviews 9. The results showed that simultaneously investment decisions and funding decisions affect the value of the company which is $22.8 \%$ and the remaining $77.2 \%$ is influenced by other variables which are not examined. Partially, the investment decision has an effect of $18.3 \%$ on the value of the company while the funding decision partially has no effect because it only affects $4.6 \%$.
\end{abstract}

Keywords: investment decisions; funding decisions; company value

\begin{abstract}
Abstrak
Penelitian ini bertujuan untuk mengetahui pengaruh keputusan investasi dan pendanaan terhadap nilai perusahaan pada perusahaan sektor pertanian sub sektor perkebunan yang terdaftar di Bursa Efek Indonesia periode 2008-2017. Metode penelituan yang digunakan adalah deskriptif dan verifikatif. Sampel yang digunakan sebanyak 6 perusahaan. Pengambilan sampel dilakukan dengan cara purposive sampling. Sedangkan, metode analisis data yang digunakan adalah analisis regresi data panel dan koefisien determinasi. Proses analisis statistik menggunakan Eviews 9. Berdasarkan hasil penelitian yang telah dilakukan dapat dilihat bahwa secara simultan keputusan investasi dan keputusan pendanaan berpengaruh terhadap nilai perusahaan yaitu sebesar $22,8 \%$ dan sisanya $77,2 \%$ dipengaruhi oleh variabel lain yang tidak diteliti. Secara parsial keputusan investasi berpengaruh sebesar $18,3 \%$ sedangkan keputusan pendanaan secara parsial tidak berpengaruh terhadap nilai perusahaan, karena hanya memberikan pengaruh sebesar $4,6 \%$.
\end{abstract}

Kata Kunci: keputusan investasi; keputusan pendanaan; nilai perusahaan 


\section{PENDAHULUAN}

Perkembangan ekonomi yang semakin meningkat pesat di Indonesia saat ini menyebabkan timbulnya persaingan dunia bisnis. Dampaknya, suatu perusahaan harus bersaing denggan perusahaan lain agar perusahaan tersebut dapat mempertahankan kelangsungan hidup dan meningkatkan nilai perusahaan serta melakukan pengembangan untuk perluasan pasar. Perusahaan memerlukan kebutuhan dana yang besar agar hal tersebut dapat tercapai. Pemenuhan dana yang dibutuhkan perusahaan memerlukan investasi yang besar dan hal tersebut menjadi permasalahan tersendiri bagi perusahaan karena bagian ini berkaitan dengan berbagai pihak, seperti kreditur, pemegang saham, seta pihak manajemen perusahaan itu sendiri.

Salah satu sektor yang memiliki peran penting di pasar modal indonesia adalah sektor pertanian. Sektor pertanian merupakan sektor yang berperan penting dalam perekonomian nasional dan kelangsungan hidup masyarakat serta kemakmuran maupun kesejahteraan masyarakat. Sektor pertanian adalah sektor yang potensial untuk dikembangkan di Indonesia, munculnya industriindustri besar berbasis agribisnis seharusnya menjadi salah satu faktor pendorong maju dan berkembangnya sektor pertanian. Kendala yang muncul saat ini adalah belum maksimalnya pemanfaatan sektor pertanian secara profesional dan berskala makro dengan ditunjuan oleh sedikitnya perusahaan agribisnis yang tercatat di pasar modal Pemilihan subsektor perkebunan dalam penelitian ini karena yang memicu sektor pertanian bisa tumbuh adalah subsektor perkebunan, dan juga karena mayoritas penduduk indonesia yang tinggal di pedesaan mempunyai mata pencaharian sebagai petani khususnya dibidang perkebunan dan Indonesia juga mempunyai sumber daya yang memadai dalam bidang perkebunan. Pengembangan sub sektor perkebunan ini memberikan kontribusi yang cukup besar pada pembangunan nasional ini berarti meningkatkan kesejahteraan hidup petani dan masyrakat pedesaan yang pada gilirannya akan meningkatkan taraf hidup sebagian masyarakat Indonesia dan juga pada akhirnya akan meningkatkan pendapatan nasional secara keseluruhan (http://infosawit.com).

Selain itu pemilihan subsektor perkebunan ini dilihat juga dari rata-rata harga saham subsektor perkebunan yang mampu mengungguli dibandingkan subsektor perikanan dan sub sektor lainnya yang ada di sektor pertanian, tetapi subsektor perkebungan juga mengalami penurunan harga saham selama 5 (lima) tahun berturutturut tidak seperti yang dialami subsektor dan subsektor lainnya yang mengalami fluktuasi.

Gambar 1 adalah data perkembangan rata-rata harga saham perusahaan sektor pertanian yang terdaftar di Bursa Efek Indonesia periode 2008-2017.

Menurunnya harga saham pada subsektor perkebunan yaitu karena terpengaruh oleh penurunan harga komoditas $\mathrm{CPO}$ (crude palm oil) dunia yang terjadi selama semester I 2014. Selain itu belum maksimalnya penyerapan produksi dalam negeri melalui biodisel juga menjadi penyebab menurunnya harga komoditas ini (http://sumatera.bisnis.com). Selain itu pada tahun 2015 terdapat masalah juga yaitu luas areal subsektor perkebunan mengalami perlambatan. Seperti komoditas karet, yang luas lahan arealnya relatif tidak berubah dalam empat tahun terakhir, serta masalah produktivitas cenderung mengalami perlambatan. Perlambatan ini disebabkan oleh ekspektasi investor yang beranggapan investasi di subsektor perkebunan tidak lagi memberikan return of investment yang menarik, serta kegiatan riset yang tidak memadai karena kurang mendapatkan dukungan pendanaan.

Ada beberapa hal yang mengemukakan tujuan dari berdirinya sebuah perusahaan. Tujuan yang pertama adalah untuk mencapai keuntungan maksimal atau laba yang sebesar-besarnya. Tujuan yang kedua adalah ingin memakmurkan pemilik perusahaan atau para pemilik saham. Sedangkan tujuan perusahaan yang ketiga adalah memaksimalkan nilai perusahaan yang tercermin pada harga sahamnya. Ketiga tujuan perusahaan tersebut sebenarnya secara substansial tidak banyak berbeda. Hanya saja penekanan yang ingin dicapai oleh masing-masing peusahaan berbeda antara yang satu dengan yang lainnya (Agus Harjito dan Martono, 2010:2). Memaksimalkan nilai perusahaan saat ini disepakati sebagai tujuan setiap perusahaan. Nilai perusahaan diyakini tidak hanya mencerminkan kinerja perusahaan saat ini tetapi juga menggambarkan prospek perusahaan di masa yang akan datang, nilai perusahaan merupakan kondisi tertentu yang telah dicapai oleh suatu perusahaan sebagai gambaran dari kepercayaan masyarakat terhadap perusahaan setelah melalui suatu proses kegitan selama beberapa tahun, yaitu sejak perusahaan tersebut didirikan sampai dengan saat ini.

Terdapat beberapa rasio untuk mengukur nilai pasar perusahaan selain melihat dari harga saham perusahaan tersebut di pasar, salah satunya yaitu dengan price book value. Rasio ini digunakan sebagai indikator nilai perusahaan dikarenakan price book value ini juga memberikan pengaruh terhadap harga saham. Perusahaan yang berjalan dengan baik, umumnya memiliki rasio price book value mencapai di atas 1 (satu) yang menunjukan bahwa nilai pasar saham lebih besar daripada nilai buku per lembar saham. Semakin besar nilai perusahaan menunjukkan bahwa pasar percaya terhadap prospek perusahaan. Rendahnya nilai perusahaan, mengindikasi rendahnya kepercayaan pasar terhadap prospek perusahaan yang berakibat pada turunnya permintaan saham dan berimbas pula dengan menurunnya harga saham dari sektor tersebut. Price book value memiliki peran penting sebagai suatu pertimbangan bagi investor untuk memilih saham yang akan dibeli dan dapat juga dijadikan indikator 
harga atau nilai saham. Price book value yang tinggi mencerminkan tingkat kemakmuran para pemegang saham, dimana kemakmuran bagi pemegang saham merupakan tujuan utama dari perusahaan (Brigham dan Houston, 2011:92).

Manajemen keuangan menyangkut penyelesaian atas keputusan penting yang diambil perusahaan, antara lain keputusan investasi. Keputusan investasi merupakan hal yang paling penting ketika perusahaan ingin menciptakan nilai perusahaan, sehingga keputusan investasi merupakan salah satu bagian dari fungsi manajemen keuangan suatu perusahaan. Manajemen keuangan harus mengalokasikan dana kedalam bentukbentuk investasi yang akan dapat mendatangkan keuntungan di masa yang akan datang. Bentuk, macam dan komposisi ada beberapa hal yang mendasar dalam proses keputusan investasi, yaitu pemahaman hubungan antara return harapan dan risiko investasi. Semakin besar return harapan suatu investasi, maka semakin besar pula risiko yang harus di petimbangkan oleh investor (Van Horne dan Wachowicz, 2012:3).

Keputusan investasi dalam penelitian ini diukur menggunakan proksi IOS berdasarkan investasi (investment-based-proxies) menurut Kallapur \& Trombley (2001) dalam Fenandar dan Raharja (2012) yaitu Ratio Capital Expenditure to Book Value of Asset (RCE/BVA). Menurut Fenandar dan Raharja (2012) keputusan investasi yang dilakukan perusahaan dilihat dari indikator-indikator yang dianggap penting dalam pengambilan keputusan perusahaan adalah indikator yang mencerminkan kesempatan investasi dimasa yang akan datang (investment opportunity). Idikator kesempatan investasi dimasa yang akan datang salah satunya adalah ratio capital expenditure to book value assets. Rasio ini menunjukkan adanya aliran tambahan aktiva produktifnya yang sekaligus menunjukkan adanya potensi pertumbuhan perusahaan.

Keputusan pendanaan berkaitan dengan penentuan struktur modal yang tepat bagi perusahaan. Tujuan dari keputusan pendanaan adalah bagaimana perusahaan menentukan sumber dana yang optimal untuk mendanai berbagai alternatif investasi, sehingga dapat memaksimalkan nilai perusahaan yang tercermin pada harga sahamnya, Untuk mendanai berbagai alternatif investasi, maka perusahaan harus menentukan sumber dana yang optimal agar dapat memaksimalkan nilai perusahaan. Sumber pendanaan perusahaan terrsebut dapat berasal dari internal financing (berupa saham laba ditahan dan depresiasi) seta external financing (utang dan ekuitas). Struktur modal perusahan merupakan long term financial structure perusahaan.

Pada penelitian ini rasio yang digunakan untuk mengukur keputusan pendanaan adalah Debt to Equity Ratio (DER). DER merupakan rasio yang digunakan menilai utang dengan ekuitas (Kasmir 2016:157). Rasio ini dapat melihat seberapa jauh perusahaan dibiayai oleh pihak luar dengan kemampuan perusahaan yang digambarkan oleh modal. Para pemberi pinjaman menginginkan rasio ini semakin rendah. Semakin rendah rasio ini, semakin tinggi tingkat pendanaan perusahaan yang di sediakan oleh pemegang saham dan semakin besar batas pengaman pemberi pinjaman jika terjadi kerugian.

Rumusan masalah adalah: (1) Bagaimana kondisi keputusan investasi, keputusan pendanaan dan nilai perusahaan pada perusahaan sektor pertanian sub sektor perkebunan yang terdaftar di Bursa Efek Indonesia periode 2008-2017, (2) Seberapa besar pengaruh keputusan investasi dan keputusan pendanaan secara simultan dan parsial terhadap nilai perusahaan pada perusahaan sektor pertanian sub sektor perkebunan yang terdaftar di Bursa Efek Indonesia periode 20082017.

Menurut Sutrisno (2012:5), keputusan investasi adalah masalah bagaimana manajer keuangan harus mengalokasikan dana ke dalam bentuk-bentuk investasi yang akan dapat mendatangkan keuntungan di masa yang akan datang. Keputusan investasi diukur menggunakan ratio capital expenditure to book value assets, menurut Fenandar dan Raharja (2012) dapat dirumuskan sebagai berikut:

$$
\mathrm{RCE} / \mathrm{BVA}=\frac{\text { Pertumbuhan Aktiva }}{\text { Total Aktiva }} \mathrm{X} 100 \%
$$

\section{Keterangan: \\ RCE/BVA $=$ Ratio Capital Expenditure to Book Value of Asset \\ Pertumbuhan Aktiva $=$ Aktiva Tetap Tahun $\mathrm{t}-$ Aktiva Tetap Tahun t-1}

Keputusan pendanaan menurut Husnan dan Pudjiastuti (2012: 251) adalah menyangkut keputusan tentang bentuk dan komposisi pendanaan yang akan dipergunakan oleh perusahaan. Keputusan pendanaan menurut Husnan dan Pudjiastuti (2012:270) diukur menggunakan debt to equity ratio dapat dihitung dengan menggunakan rumus sebagai berikut:

$$
\text { Debt to Equity Ratio }=\frac{\text { Total Debt }}{\text { Total Equity }}
$$

Husnan dan Pudjiastuti (2012:6), mendefinisikan nilai perusahaan merupakan tujuan normatif dari manajemen keuangan. Nilai perusahaan adalah harga yang bersedia dibayarkan oleh pembeli atau investor apabila suatu perusahaan dijual. Semakin tinggi nilai perusahaan, semakin besar kemakmuran yang akan diterima oleh pemilik perusahaan. Nilai perusahaan menurut Suad Husnan dan Enny Pudjiastuti (2012:7) dapat diukur dengan rasio Price Book Value (PBV) sebagai berikut: 


$$
\mathrm{PBV}=\frac{\text { Harga Pasar }}{\text { Nilai Buku Per Lembar Saham }}
$$

\section{Keterangan:}

PBV = Price Book Value

Nilai Buku Per Lembar Saham = Total Ekuitas/Jumlah Lembar Saham yang Beredar

Nilai perusahaan sangat penting karena mencerminkan harga saham, kinerja perusahaan, dan kemakmuran pemegang saham yang dapat mempengaruhi persepsi investor terhadap peusahaan. Perusahaan mengharap manajer keuangan akan melakukan tindakan terbaik dengan memaksimalkan nilai perusahaan sehingga kemakmuran pemegangan saham dapat tercapai. Hasil penelitian Fenandar dan Surya Raharja (2012), Prasetuo, et. al. (2013), Doust \& Pakmaram (2015), Hajering, et. al. (2018), Arifah dan Roifah (2015) bahwa keputusan investasi dan keputusan pendanaan secara bersama-sama berpengaruh secara simultan terhadap nilai perusahaan

Tugas manajemen keuangan yang dilakukan secara rutin adalah bagaimana mengatur aliran dana agar operasi perusahaan berjalan dengan baik. Di samping itu, manajer keuangan mempunyai tugas cukup berat yaitu membuat keputusan investasi. Keputusan ini sangat penting dengan semakin besarnya dan berkembangnya perusahaan. Semakin perusahaan berkembang, maka manajemen dituntut mengambil keputusan investasi, seperti pembukaan cabang, perluasan usaha, maupun pendirian lainnya (Sutrisno, 2012:121).

Penelitian yang dilakukan oleh Afzal dan Rohman (2012), Suroto (2015), Ningrum dan Priyadi (2017), Triani dan Tarmidi (2019), Mursalim, et. al (2015), Efni (2017), Arifah dan Roifah (2015) menyebut bahwa adanya pengaruh keputusan investasi terhadap nilai perusahaan, menunjukkan bahwa kemampuan perusahaan memaksimumkan investasi dalam upaya menghasilkan laba sesuai dengan jumlah dana yang terkait. Keputusan investasi berpengaruh positif terhadap nilai perusahaan. Pengeluaran modal perusahaan (capital expenditure) sangat penting meningkatkan nilai perusahaan karena jenis investasi ini memberikan sinyal tentang pertumbuhan pendapatan yang diharapkan di masa mendatang meningkatkan nilai pasar perusahaan.

Diperkuat dengan Signalling Theory yang dikemukakan Michael Spense (1973). Teori tersebut menyatakan bahwa pengeluaran investasi memberikan sinyal positif terhadap pertumbuhan perusahaan di masa yang akan datang, sehingga meningkatkan harga saham sebagai indikator nilai perusahaan. Teori ini menunjukkan bahwa pengeluaran investasi yang dilakukan oleh perusahaan memberikan sinyal, khususnya kepada investor maupun kreditur bahwa perusahaan tersebut akan tumbuh dimasa mendatang.
Keputusan pendanaan menurut Husnan dan Pudjiastuti (2012:251) menyangkut keputusan tentang bentuk dan komposisi pendanaan yang akan dipergunakan oleh perusahaan. Keputusan pendanaan oleh manajemen akan berpengaruh pada penilaian perusahaan yang terefleksi di harga saham. Oleh karena itu, salah satu tugas manajemen keuangan adalah menentukan kebijakan pendanaan yang dapat memaksimalkan harga saham yang merupakan cerminan dari suatu nilai perusahaan (Harmono, 2009).

Berdasarkan penelitian Afzal dan Rohman (2012), Sartini dan Purbawangsa (2013), Ningrum dan Priyadi (2017), Nasrum, et. al. (2015), Arifah dan Roifah (2015) keputusan pendanaan berpengaruh positif terhadap nilai perusahaan. Besar kecilnya rasio keputusan pendanaan menjadi faktor langsung yang dapat menjadi pertimbangan bagi investor untuk menanamkan modalnya pada perusahaan. Keputusan pendanaan dengan menggunakan ekuitas lebih banyak daripada hutang, sehingga laba yang diperoleh akan semakin besar. Hipotesis yang diajukan adalah terdapat pengaruh keputusan investasi dan keputusan pendanaan terhadap nilai perusahaan, baik secara simultan maupun parsial.

\section{METODE}

Metode yang digunakan adalah metode deskriptif dan metode verifikatif. Populasi adalah perusahaan sektor pertanian sub sektor perkebunan yang terdaftar di Bursa Efek Indonesia periode 2008-2017 yaitu sebanyak 16 perusahaan. Teknik pengambilan sampel menggunakan metode purposive sampling, sebanyak 6 perusahaan yaitu Gozco Plantation Tbk, PP London Sumatera Indonesia Tbk, Sampoerna Agro Tbk, Smart Tbk, Tunas Baru Lampung Tbk, Bakrie Sumatera Plantation Tbk.

Teknik pengumpulan data yang dilakukan adalah studi kepustakaan dan observasi tidak langsung dengan cara mengumpulkan data laporan keuangan tahunan, gambaran umum serta perkembangan perusahaan sektor pertanian sub sektor perkebunan di Bursa Efek Indonesia dengan mengakses langsung ke situs www.idx.co.id dan data dari ICMD. Teknik analisis data menggunakan analisis regresi data panel (pooled data), dan koefisien determinasi menggunakan software Microscoft excel, SPSS dan Eviews 9.

\section{HASIL}

Kondisi Keputusan Investasi pada Perusahaan Sektor Pertanian Sub Sektor Perkebunan yang terdaftar di Bursa Efek Indonesia (BEI) periode 2008-2017 ditunjukkan pada Gambar 2.

Berdasarkan Gambar 2, kondisi keputusan investasi dengan menggunakan Ratio Capital Expenditure to Book Value of Asset (RCE/BVA) dapat diketahui mengalami fluktuasi dengan cenderung mengalami 
penurunan. Penurunan ini disebabkan oleh terjadi keluarnya aliran modal asing dari Indonesia yang dipicu oleh persepsi negatif investor asing terhadap tekanan inflasi yang sempat tinggi pasca kenaikan harga BBM bersubsidi. Faktor lain yang mempengaruhi naik turunnya keputusan investasi yaitu tingkat keuntungan yang didapat perusahaan menurut (http:// www.indonesia-investments.com). Selain itu kenaikan keputusan investasi ini juga dapat diakibatkan oleh pertumbuhan aktiva atau aktiva tetap yang tinggi dan turunnya total aktiva perusahaan tersebut.

Kondisi keputusan pendanaan pada perusahaan sektor pertanian sub sektor perkebunan yang terdaftar di Bursa Efek Indonesia (BEI) periode 2008-2017 ditunjukkan pada Gambar 3.

Berdasarkan Gambar 3, kondisi rata-rata keputusan pendanaan dengan menggunakan Debt to Equity Ratio (DER) dapat diketahui mengalami fluktuasi dengan kecenderungan mengalami kenaikan. Kenaikan ini disebabkan oleh dikarenakan adanya kenaikan liabilitas imbalan kerja dan terjadinya penurunan harga CPO, akibat melemahnya permintaan pasar global terhadap karet natural dan tingkat produksi dunia yang berlebihan. Penurunan nilai debt to equity ratio tersebut diakibatkan kerena adanya peningkatan ekutas perusahaan sehingga perusahaan cenderung lebih besar menggunaan modal sendiri yang di miliki perusahaan dibandingkan menggunakan hutang. Karena investor lebih menyukai dengan nilai DER yang rendah.

Kondisi Nilai Perusahaan pada Perusahaan Sektor Pertanian Sub Sektor Pertanian Sub Sektor Perkebunan yang terdaftar di Bursa Efek Indonesia (BEI) periode 2008-2017 ditunjukkan pada Gambar 4.

Berdasarkan Gambar 4, kondisi rata-rata kondisi nilai menggunakan Price Book Value (PBV) dapat diketahui mengalami fluktuasi dengan kecenderungan mengalami penurunan. Penurunan ini disebabkan oleh terpengaruh oleh penurunan harga komoditas CPO (crude palm oil) dunia yang terjadi selama semester I 2014. Selain itu belum maksimalnya penyerapan produksi dalam negeri melalui biodisel dan masih terdapat luas lahan areal yang tidak berubah atau mengalami perlambatan, Perlambatan ini disebabkan oleh ekspektasi investor yang beranggapan investasi di subsektor perkebunan tidak lagi memberikan return of investment yang menarik, serta kegiatan riset yang tidak memadai karena kurang mendapatkan dukungan pendanaan.

Pemilihan model regresi data panel dengan uji Chow (Chow Test) ditunjukkan pada Tabel 1.

Berdasarkan Tabel 1 diperoleh nilai probability $\mathrm{F}$ adalah 0,000 , model yang terpilih adalah model fixed effect. Pengujian dilanjutkan menggunakan uji Hausman untuk memilih model antara fixed effect dan random effect (Tabel 2).

Berdasarkan Tabel 2 diperoleh nilai probability $\mathrm{F}$ adalah 0,6095 , artinya model yang terpilih adalah model random effect. Pengujian dilanjutkan menggunakan uji Langrange Multiplier untuk memilih model antara random effect dan common effect (Tabel 3 ).

Berdasarkan Tabel 3 dapat diketahui bahwa hasil Both Breusch-Pagan adalah sebesar 0,000, artinya random effect merupakan pilihan yang tepat untuk estimasi model. Hasil uji asumsi klasik, menunjukkan bahwa data berdistribusi normal, tidak terjadi multikolinieritas, tidak ada masalah heteroskedistisitas, dan autokorelasi. Hasil analisis regresi data panel ditunjukkan pada Tabel 4.

Berdasarkan Tabel 4, dapat diketahui bahwa keputusan investasi dan keputusan pendanaan berpengaruh terhadap nilai perusahaan pada perusahaan sektor pertanian sub sektor perkenbunan yang terdaftar di Bursa Efek Indonesia periode 2008-2017, dengan persamaan sebgai berikut:

$$
\mathrm{Y}=1,097+0,059 \mathrm{X}_{1}-0,129 \mathrm{X}_{2}+\mathrm{e} .
$$

\section{Dimana :}

$\mathrm{Y}=$ Nilai Perusahaan

$\mathrm{X}_{1}=$ Keputusan Investasi

$\mathrm{X}_{2}=$ Keputusan Pendanaan

Pengujian hipotesis secara simultan ditunjukkan pada Tabel 5. Berdasarkan Tabel 5 dapat diketahui nilai Fhitung secara simultan pada keputusan investasi dan keputusan pendanaan terhadap nilai perusahaan sebesar 8,460 dengan nilai probability sebesar 0,0006 . Artinya keputusan investasi dan keputusan pendanaan simultan berpengaruh terhadap nilai perusahaan pada perusahaan sektor pertanian sub sektor perkebunan yang terdaftar di Bursa Efek Indonesia periode 2008-2017.

Hasil pengujian secara parsial ditunjukkan pada Tabel 6. Berdasarkan Tabel 6 dapat diketahui bahwa keputusan investasi berpengaruh terhadap nilai perusahaan pada perusahaan sektor pertanian sub sektor perkebunan yang terdaftar di Bursa Efek Indonesia periode 2008-2017, sedangkan keputusan pendanaan tidak berpengaruh signifikan. Perhitungan koefisien determinasi secara simultan ditunjukkan pada Tabel 7.

Berdasarkan Tabel 7, diperoleh nilai R-Square sebesar 0,228 atau 22,8 persen. Artinya keputusan investasi dan keputusan pendanaan secara simultan memberikan kontribusi atau pengaruh sebesar 22,8\% terhadap nilai perusahaan pada perusahaan sektor pertanian sub sektor perkebunan yang terdaftar di Bursa Efek Indonesia. Sisanya dipengaruh faktor-faktor lain yang tidak diteliti sebesar $77,2 \%$, yaitu merupakan pengaruh faktor lain di luar keputusan investasi dan keputusan pendanaan. Hasil perhitungan koefisien determinasi parsialditunjukkan pada Tabel 8 .

Berdasarkan Tabel 8, koefisien determinasi parsial sebagai berikut: (1) Pengaruh keputusan investasi terhadap nilai perusahaan $=0,489 \times 0,375=0,183$ atau $18,3 \%$, (2) Pengaruh keputusan pendanaan terhadap nilai perusahaan $=-0,195 \mathrm{x}-0,235=0,046$ atau $4,6 \%$ 


\section{PEMBAHASAN}

Hasil pengolahan data menggunakan Eviews 9 menunjukkan nilai probability 0,0006 yang berarti keputusaan investasi dan pendanaan mempengaruhi nilai perusahaan pada perusahaan sektor pertanian sub sektor perkebunan yang terdaftar di Bursa Efek Indonesia periode 2008-2017 dengan pengaruh sebesar 22,8\%. Hasil penelitian ini sejalan dengan Afzal dan Rohman (2012), Sartini dan Purbawangsa (2013), Prasetyo, et. al. (2013), Fenandar dan Raharja (2012), Doust \& Pakmaran (2015), Hajering, et. al. (2018), Arifah dan Roifah (2015) bahwa keputusan investasi dan pendanaan berpengaruh secara simultan dan signifikan terhadap nilai perusahaan.

Secara parsial keputusan investasi akan mempengaruhi nilai perusahaan dengan kontribusi sebesar $18,3 \%$. Hal ini sesuai dengan hasil penelitian oleh Afzal dan Rohman (2012) bahwa keputusan investasi berpengaruh positif dan signifikan terhadap nilai perusahaan, menunjukkan bahwa kemampuan perusahaan memaksimumkan investasi dalam upaya menghasilkan laba sesuai dengan jumlah dana yang terkait dan efek langsung keputusan investasi terhadap nilai perusahaan merupakan hasil yang diperoleh dari kegiatan investasi itu sendiri melalui pemilihan proyek atau kebijakan lainnya seperti menciptakan produk baru, penggantian mesin yang lebih efisien. Suroto (2015), Ningrum dan Priyadi (2017), Triani dan Tarmidi (2019), Mursalim, et. al. (2015), Efni (2017), Arifah dan Roifah (2015) dalam penelitiannya menyebutkan bahwa keputusan investasi berpengaruh positif terhadap nilai perusahaan. Penelitian ini diperkuat dengan Signalling Theory yang dikemukakan Michael Spense (1973). Teori tersebut menyatakan bahwa pengeluaran investasi memberikan sinyal positif terhadap pertumbuhan perusahaan di masa yang akan datang, sehingga meningkatkan harga saham sebagai indikator nilai perusahaan. Teori ini menunjukkan bahwa pengeluaran investasi yang dilakukan oleh perusahaan memberikan sinyal, khususnya kepada investor maupun kreditur bahwa perusahaan tersebut akan tumbuh di masa mendatang.

Hasil penelitian menunjukkan bahwa besar kecilnya keputusan pendanaan tidak akan mempengaruhi nilai perusahaan pada perusahaan tersebut karena hanya memberikan pengaruh sebesar $4,6 \%$ dan tidak signifikan. Hasil ini tidak sejalan dengan penelitian yang dilakukan oleh Afzal dan Rohman (2012), Sartini dan Purbawangsa (2013) dan Ningrum dan Priyadi (2017), Nasrum, et. al. (2015), Arifah dan Roifah (2015) diketahui bahwa keputusan pendanaan berpengaruh signifikan terhadap nilai perusahaan secara parsial. Tetapi hasil penelitian sejalan dengan penelitian yang dilakukan oleh Faridah (2016), Efni (2017), Fajaria, et. al. (2017) bahwa keputusan pendanaan tidak berpengaruh secara signifikan terhadap nilai perusahaan, dengan asumsi apabila perusahaan menghasilkan laba, prioritas utama perusahaan adalah membayar hutang daripada mensejahterakan kemakmuran pemegang saham, sehingga nilai perusahaan akan menurun. Tidak signifikannya keputusan pendanaan ini disebabkan oleh hutang yang merupakan satu sumber pembiayaan dengan risiko tinggi.

\section{KESIMPULAN}

Kesimpulan penelitian ini adalah sebagai berikut: (1) Keputusan investasi dan nilai perusahaana pada perusahaan sektor pertanian sub sektor perkebunan yang terdaftar di Bursa Efek Indonesia periode 2008-2017 cenderung menurun, sedangkan keputusan pendanaan cenderung meningkat. (2) Besarnya pengaruh keputusan investasi dan pendanaan terhadap nilai perusahaan secara simultan sebesar $22,8 \%$. Besarnya pengaruh keputusan investasi terhadap nilai perusahaan secara parsial sebesar 18,3\% signifikan, sedangkan pengaruh keputusan pendanaan terhadap nilai perusahaan secara parsial sebesar $4,6 \%$ dan tidak sgnifikan.

\section{DAFTAR PUSTAKA}

Afzal, Ari dan Abudul Rohman. 2012. Pengaruh Keputusan Investasi, Keputusan Pendanaan dan Kebijakan Dividen Terhadap Nilai Perusahaan pada Perusahaan Manufaktur Periode 2007-2010, Journal of Accounting, Vol.1, No.2.

Arifah, Dista Amalia dan Siti Roifah. 2015. The Effect of Investment Decision, Funding Decision, and Dividend Policy on Corporate Value. research. unissula.ac.id/file/publikasi/211406020

Brigham, Eugene F. dan Houston, Joel, F. Houston. 2011. Dasar-dasar Manajemen Keuangan, Edisi 11, Penerjemah Ali Akbar Yulianto. Salemba Empat. Jakarta.

Doust, Afshin Najafgholi dan Asgar Pakmaram. 2015. The influence of decisions investment, funding decisions and dividend policy of the company study includes companies listed in Tehran Stock Exchange periode 2008-2014. International Journal of Academic Research in Accounting, Finance and Management Sciences Vol. 5, No.3, July 2015, pp. 14-32.

Nasrum, Muhammad; Dahlan; Abdul Hamid Burhami. 2015. The Effect of Ownership Structure, Corporate Governance, Investment Decision, Financial Decision and Dividend Policy on the Value of the Firm Manufacturing Companies Listed on Indonesian Stock Exchange Periode 2000-2009. British Journal of Economics, Finance and Management Sciences, July 2015, Vol. 10 (2).

Efni, Yulia 2017. The Mediating Effect of Investment Decisions and Financing Decisions on The Effect Corporate Risk and Dividend Policy Against Corporate Value.Investment Management and Financial Innovations, Volume 14, Issue 2.

Fajaria, Ardina Zahrah; Linda Purnamasari, and Isnalita. 
2017. The Effect of Investmnet Decision, Funding Decisions, and Dividend Policy on Company Value. Study on Manufacturing Company Listed in Indonesia Stock Exchange Period 2009 - 2013. Advances in Economics and Management Research, Vol. 35. Mulawarman International Coferrence on Economics and Business (MICEB). Atlantis Press.

Faridah, Nur. 2016. Pengaruh Keputusan Investasi, Pendanaan, Kebijakan Dividen, Tingkat Suku Bunga terhadap Nilai perusahaan pada perusahaan yang terdaftar di (BEI) tahun 2012-2014. Jurnal Ilmu dan Riset akuntasi: Volume 5. Nomor 2.

Fenandar, Gany Ibrahim dan Surya Raharja. 2012. Pengaruh Keputusan Investasi, Keputusan Pendanaan, dan Kebijakan Dividen Terhadap Nilai Perusahaan Studi Kasus pada Perusahaan Manufaktur yang Terdaftar di BEI Periode 2007-2010. Journal of Accounting. Vol.1, No.2, Tahun 2012, hal.1-10.

Hajering; Mahfudnurnajamuddin; Ibrahim Dani; and Muhammad Su'un. 2018. The Influence of Investment Decisions, Funding Decisions, and Dividend Policies On Financiak Performance and The Value of Banking Companies Listed In Indonesia Stock Exchange. International Journal of Business and Management Invention (IJBMI), Vol. 7, Isuue 10, Ver 1, October.

Harjito, Agus dan Martono. 2010. Manajemen Keuangan, edisi 3. Ekonisia, Yogyakarta.

Harmono. 2009. Manajemen Keuangan Berbasis Balanced Scorecard (Pendekatan Teori, Kasus dan Riset Bisnis). Bumi Aksara. Jakarta.

Horne, James C. Van dan John M Wachowicz, Jr. 2012. Prinsip-prinsip Manajemen Keuangan. Edisi 13. Salemba Empat. Jakarta.

Husnan, Suad dan Enny Pudjiastuti. 2012. Dasar-dasar Manajemen Keuangan. Edisi 6. UPP STIM YKPN. Yogyakarta.

Kasmir. 2016. Analisis Laporan Keuangan, Raja Grafindo Persada, Jakarta.

Mursalim; Hendragunawan S. Thayf; dan Abdullah Sanusi. 2015. Financial decision, investment decision, profitability and company value: study on manufacturing company listed in indonesian stock exchange periode 2008-2013. Information Management and Business Review Vol. 7, No. 2, pp. 72-78, April.

Ningrum, Frista Cahya dan Maswar Patuh Priyadi. 2017. Pengaruh Keputusan Investasi, Pendanaan, Kibajak Dividen dan Suku Bunga Terhadap Nilai Perusahaan pada Perusahaan Manufaktur yang Terdaftar di Bursa Efek Indonesia (BEI) Tahun 2010-2015, Jurnal Ilmu dan Riset Akuntansi, Vol.6, No. 4, April 2017.

Prasetyo, Dimas; Zahroh Z. A, dan Farah Devi Azizah. 2013. Pengaruh Keputusan Investasi dan Keputusan Pendanaan Terhadap Nilai Perusahaan Studi pada Perusahaan Sektor sektor pertanian yang Terdaftar di BEI Periode 2009-2011. Fakultas Ilmu Administrasi. Universitas Brawijaya.

Sartini, Luh Putu Novita dan Ida Bagus Anom Purbawangsa. 2013. Pengaruh Keputusan Investasi, Kebijakan Dividen, serta Keputusan Pendanaan Terhadap Nilai Perusahan pada Perusahaan Manufaktur yang Terdaftar di BEI Periode 20092011. Fakultas Ekonomi dan Bisnis Universitas Udayana, Bali, Indonesia.

Suroto. 2015. Pengaruh Keputusan Investasi, Keputusan Pendanaan dan Kebijakan Dividen Terhadap Nilai Perusahaan Studi Empiris pada perusahaan LQ-45 yang Terdaftar di BEI Periode Februari 2010-Januari 2015. Jurnal Ilmiah Untang Semarang, Vol.4, No.3., hal 634-645.

Sutrisno. 2012. Manajemen Keuangan: Teori, Konsep, dan aplikasi, edisi Pertama, Ekonisia, Yogyakarta.

Triani, Nur dan Deden Tarmidi. 2019. Firm Value: Impact of Investment Decision, Funding Decision and Dividend Policy. International Journal of Academic Research in Accounting, Finance and Management Science. Vol. 9, No. 2, pp. $158-163$.

www.idx.co.id

http://infosawit.com

http://www.indonesia-investments.com/

Rata-Rata Harga Saham Sektor Pertanian

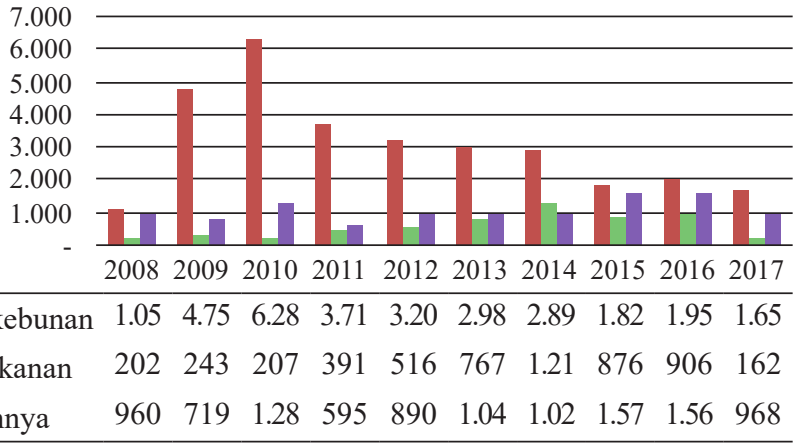

Sumber : www.idx.co.id (Data yang tersedia diolah kembali

Gambar 1. Grafik Rata-Rata Harga Saham Sektor Pertanian yang

Terdaftar di Bursa Efek Indonesia (BEI) Periode 2008-2017 
Keputusan Investasi (RCE/BVA)

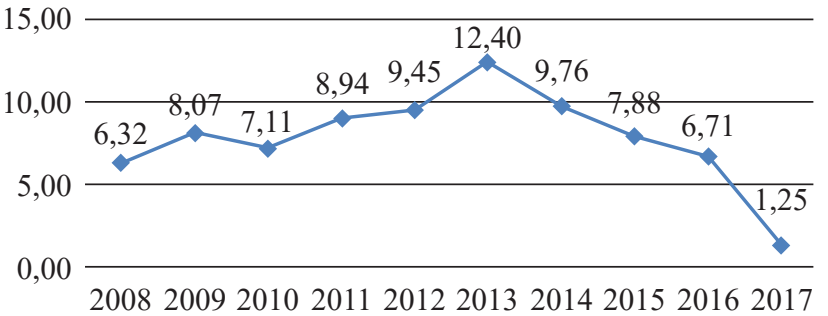

Sumber: Data sekunder yang diolah peneliti

Gambar 2. Kondisi Rata-rata Keputusan Investasi pada Perusahaan Sektor Pertanian Sub Sektor Perkebunan yang terdaftar di Bursa Efek Indonesia selama periode tahun 2008-2017

Keputusan Pendanaan (DER)

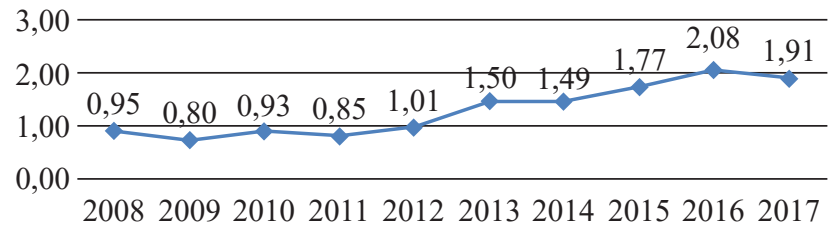

Sumber: Data sekunder yang diolah peneliti

Gambar 3. Kondisi Rata-rata Keputusan Pendanaan pada Perusahaan Sektor Pertanian Sub Sektor Perkebunan yang terdaftar di Bursa Efek Indonesia selama periode tahun 2008-2017

Nilai Perusahaan (PBV)

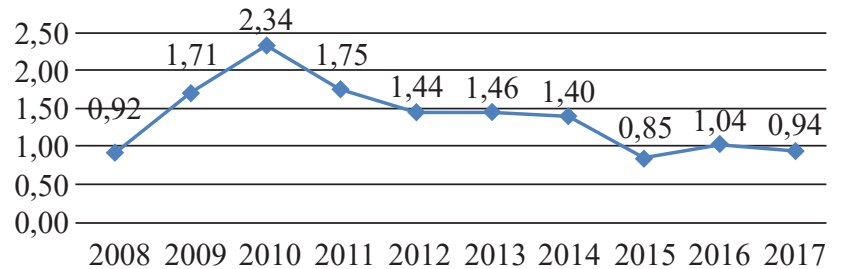

Sumber: Data sekunder yang diolah peneliti

Gambar 4. Kondisi rata-rata kondisi Nilai Perusahaan pada Perusahaan Sektor Pertanian Sub Sektor Perkebunan yang terdaftar di Bursa Efek Indonesia selama periode tahun 2008-2017

Tabel 1. Hasil Chow Test Untuk Menguji Common/Fixed Model

\begin{tabular}{|c|c|c|c|}
\hline \multicolumn{4}{|c|}{ Redundant Fixed Effects Tests } \\
\hline \multicolumn{4}{|l|}{ Equation: CHOW_TEST } \\
\hline \multicolumn{4}{|c|}{ Test cross-section fixed effects } \\
\hline Effects Test & Statistic & d.f. & Prob. \\
\hline Cross-section F & 9.504390 & $(5,52)$ & 0.0000 \\
\hline Cross-section Chi-square & 38.948071 & 5 & 0.0000 \\
\hline
\end{tabular}

Sumber: Olah Data Eviews 9
Tabel 2. Hasil Hausman Test Untuk Menguji Random/Fixed Model

Correlated Random Effects - Hausman Test

Equation: HAUSMAN_TEST

Test cross-section random effects

\begin{tabular}{cccc}
\hline Test Summary & Chi-Sq. Statistic & Chi-Sq. d.f. & Prob. \\
\hline Cross-section random & 0.990147 & 2 & 0.6095 \\
\hline Sumber: Olah Data Eviews 9 & &
\end{tabular}

Tabel 3. Hasil Uji LM (Lagrange Multiplier Test)

Lagrange Multiplier Tests for Random Effects

Null hypotheses: No effects

Alternative hypotheses: Two-sided (Breusch-Pagan) and one-sided

\begin{tabular}{cccc}
\hline \multicolumn{3}{c}{ Test Hypothesis } \\
& Cross-section & Time & Both \\
\hline Breusch-Pagan & 38.73881 & 1.792911 & 40.53172 \\
& $(0.0000)$ & $(0.1806)$ & $(0.0000)$ \\
\hline
\end{tabular}

Sumber: Olah Data Eviews 9

Tabel 4. Analisis Regresi Data Panel

Dependent Variable: PBV

Method: Panel EGLS (Cross-section random effects)

Date: 09/19/18 Time: 10:38

Sample: 20082017

Periods included: 10

Cross-sections included: 6

Total panel (balanced) observations: 60

Swamy and Arora estimator of component variances

Cross-section weights (PCSE) standard errors \& covariance (d.f. corrected)

\begin{tabular}{lcccc}
\hline Variable & Coefficient & Std. Error & t-Statistic & Prob. \\
\hline C & 1.097397 & 0.340190 & 3.225832 & 0.0021 \\
RCE_BVA & 0.058875 & 0.015998 & 3.680215 & 0.0005 \\
DER & -0.129447 & 0.096865 & -1.336367 & 0.1867 \\
\hline
\end{tabular}

Sumber: Olah data Eviews 9

Tabel 5. Hasil Uji F

Weighted Statistics

\begin{tabular}{llll}
\hline R-squared & 0.228914 & Mean dependent var & 0.374342 \\
Adjusted R-squared & 0.201859 & S.D. dependent var & 0.642350 \\
S.E. of regression & 0.573868 & Sum squared resid & 18.77148 \\
F-statistic & 8.460880 & Durbin-Watson stat & 1.453063 \\
Prob (F-statistic) & 0.000606 & & \\
\hline
\end{tabular}

Sumber: Olah data Eviews 9 
Tabel 6. Hasil Uji t Keputusan Investasi terhadap kondisi Nilai Perusahaan

\begin{tabular}{lcccc}
\hline Variable & Coefficient & Std. Error & t-Statistic & Prob. \\
\hline C & 1.097397 & 0.340190 & 3.225832 & 0.0021 \\
RCE_BVA & 0.058875 & 0.015998 & 3.680215 & 0.0005 \\
DER & -0.129447 & 0.096865 & -1.336367 & 0.1867 \\
\hline
\end{tabular}

Sumber: Olah data Eviews 9
Tabel 7. Analisis Koefisien Determinasi Simultan

\begin{tabular}{llll}
\hline R-squared & 0.228914 & Mean dependent var & 0.374342 \\
Adjusted R-squared & 0.201859 & S.D. dependent var & 0.642350 \\
S.E. of regression & 0.573868 & Sum squared resid & 18.77148 \\
F-statistic & 8.460880 & Durbin-Watson stat & 1.453063 \\
Prob(F-statistic) & 0.000606 & &
\end{tabular}

Sumber: Olah data Eviews 9

Tabel 8. Koefisien Determinasi Parsial

Coefficients $^{\mathrm{a}}$

\begin{tabular}{|c|c|c|c|c|c|c|c|c|c|}
\hline \multirow{2}{*}{\multicolumn{2}{|c|}{ Model }} & \multicolumn{2}{|c|}{$\begin{array}{c}\text { Unstandardized } \\
\text { Coefficients }\end{array}$} & \multirow{2}{*}{$\begin{array}{c}\text { Standardized } \\
\text { Coefficients }\end{array}$} & \multirow[t]{2}{*}{$\mathrm{T}$} & \multirow[t]{2}{*}{ Sig. } & \multicolumn{3}{|c|}{ Correlations } \\
\hline & & B & Std. Error & & & & Zero-order & Partial & Part \\
\hline \multirow[t]{3}{*}{1} & (Constant) & 1,097 &, 340 & & 3,226 & ,002 & & & \\
\hline & RCE/BVA & ,059 &, 016 & ,489 & 3,680 & ,001 & ,375 & ,373 & ,343 \\
\hline & DER &,- 129 & ,097 &,- 195 & $-1,336$ & 187 &,- 235 &,- 393 &,- 224 \\
\hline
\end{tabular}

a. Dependent Variable: PBV

Sumber: Data tambahan 